\title{
EHMTI-0113. Headaches associated with symptomatic epilepsy in adults
}

\author{
$\mathrm{S} \mathrm{Atic}^{1 *}, \mathrm{D}$ Atic $^{2}$, R Amanovic Curuvija ${ }^{1}, \mathrm{M} \mathrm{Savic}^{1}$ \\ From 4th European Headache and Migraine Trust International Congress: EHMTIC 2014 \\ Copenhagen, Denmark. 18-21 September 2014
}

\section{Introduction}

Headache is a symptom very often present in patients with epilepsy.

\section{Aims}

The aim of our study was to find the characteristics of headache in adults patients with symptomatic epilepsy.

\section{Methods}

We studied patients with symptomatic epilepsy and headache using standard protocol:neurological examinations, Color duplex ultrasound, Transcranial ultrasound, Electroencephalography ( EEG), Computerized tomography (CT ) and MR/MRA (angiography).

\section{Results}

82 patients were observed, 52 female and 30 male, age range 39 to 82 .All of them were suffering by acute or chronic headache and symptomatic epilepsy. Preictal headache was present in $8(9,75 \%)$ patients, postictal in 27 ( 32,92\% ) and interictal in 47 (57,1\%) patients. Among the patients with postictal headache $13(48,14 \%)$ had migraine, $9(33,33 \%)$ tension -type of headache and 7 $(25,72 \%)$ other headaches. Among the patients with interictal headache 28 ( 59,57\% ) was migraine, 15 ( 31,91\% ) combined migraine and tension-type and 7 ( $14,89 \%)$ other headaches. The majority of seizures were symple focal seizures.

\section{Conclusions}

1)Among the patients with symptomatic epilepsy interictal migraine was commonly than other headaches.

2)The majority of seizures in patients with headache and symptomatic epilepsy were simple focal seizures.

${ }^{1}$ Neurology, Hospital for Cerebrovascular Diseases Sveti Sava, Belgrade, Serbia Full list of author information is available at the end of the article
3)The comorbidity may be important in the choice of treatment of headache.

\section{Authors' details}

${ }^{1}$ Neurology, Hospital for Cerebrovascular Diseases Sveti Sava, Belgrade, Serbia. ${ }^{2}$ General Medicine, Health Center Vozdovac, Belgrade, Serbia.

Published: 18 September 2014

doi:10.1186/1129-2377-15-S1-C4

Cite this article as: Atic et al:. EHMTI-0113. Headaches associated with symptomatic epilepsy in adults. The Journal of Headache and Pain 2014 15(Suppl 1):C4

\section{SpringerOpen $^{\circ}$}

C 2014 Atic et al; licensee Springer. This is an Open Access article distributed under the terms of the Creative Commons Attribution License (http://creativecommons.org/licenses/by/2.0), which permits unrestricted use, distribution, and reproduction in any medium, provided the original work is properly cited.
Submit your manuscript to a SpringerOpen ${ }^{\circ}$ journal and benefit from:

- Convenient online submission

- Rigorous peer review

- Immediate publication on acceptance

- Open access: articles freely available online

- High visibility within the field

- Retaining the copyright to your article

Submit your next manuscript at $>$ springeropen.com 